\title{
Maatalouden digitaaliset verkko-opetusaineistot yrittäjille
}

Anne-Mari Malvisto ${ }^{1)}$, Anna-Stina Kuula ${ }^{1)}$, Pauliina Silvennoinen ${ }^{2)}$, Susanna Lahnamäki-Kivelä ${ }^{1)}$, Jyrki Kataja ${ }^{1)}$

1) Jyväskylän ammattikorkeakoulu, Biotalousinstituutti, Tuumalantie 17, 43130 Tarvaala etunimi.sukunimi@jamk.fi

2) Jyväskylän ammattikorkeakoulu, Ammatillinen opettajakorkeakoulu, Rajakatu 35, 40100 Jyväskylä, etunimi.sukunimi@jamk.fi

\section{TIIVISTELMÄ}

Digitaalisuus tulee - eikä sitä voi estää! Aiemmissa maatalousyrittäjien koulutushankkeissa (Maitoa ja naudanlihaa Keski-Suomesta, Meka, LuomuKS) on havaittu tarve koulutusmateriaalin nykyaikaistamiselle, uusien koulutustapojen kehittämiselle ja tiedonjakamiselle. Vertaisryhmätoiminta ja tilavierailut on koettu viljelijöiden keskuudessa vaikuttavimmaksi kanavaksi lisätä oman tilan ja osaamisen kehittämistä. Tilakoon kasvaessa ajankäytön muutos aiheuttaa haasteita lähteä päivän koulutuksiin. Lisäksi sesonkiajankohtina, jolloin tiedontarve on keskeistä, lähtemistä rajoittaa aikaongelma. Verkkovälitteisellä vuorovaikutuksella ja virtuaalivierailuilla voidaan tarjota joustavat vaihtoehdot vertaisoppimiseen sekä pienentää kasvi- ja kotieläintilojen tautiriskejä.

Vertaisosaamisen sekä neuvonta- ja asiantuntijatiedon yhdistäminen digitaalisessa ympäristössä uudistaa osaamisen jakamista ja kehittämistä. MataDigi - Maatalouden digitaaliset verkkoopetusaineistot yrittäjille -hankkeessa tavoitteena on muodostaa tiedonvälitysmalleja ja hakea toimivia keinoja käytettäväksi tiedon siirtämiseksi tutkimuksesta ja vertaisyrittäjiltä kehittyvien maatalousyritysten käyttöön. Hankkeessa testataan digitaalisia tiedonvälityksen teknologioita, jotka mahdollistavat osallistuminen koulutuksiin joustavasti ja vuorovaikutuksessa vertaisten sekä asiantuntijoiden kanssa mobiilisti.

Pilottien testattavat tiedonvälitysmuodot:

1) Kyselytunti verkossa

Verkkotapaamisessa asiantuntijatiedon ja vertaiskokemukset yhdistyvät kaikkien hyödyksi. Onnistumisen edellytykset: yhteinen kiinnostava ja ajankohtainen aihe, etäosallistumismahdollisuus, verkko- ja sovellustestaus ennakkoon, helppokäyttöinen mobiilisovellus sekä yrittäjien kehittymishalu.

2) Kasvukauden seuranta Kasvukauden tilanteiden seuranta ja jakaminen lyhyillä vidoilla, keskittyen ajankohtaisiin haasteisiin. Vertaistieto ja -kokemus tukena ongelmien ratkaisuissa. Vertaiset pääsevät katsomaan videoita ja antamaan kommenttia tai vinkkejä omalla videollaan.

3) Virtuaalinen ja vuorovaikutteinen tilavierailu

Toteutetaan virtuaalinen tilavierailu. Osallistujat pääsevät vierailemaan etänä livetilanteessa kiinnostavassa kohteessa. Mukana vierailulla ovat esim. eläinlääkäri ja vierailutilan isäntä/emäntä. Livetilanne mahdollistaa keskinäisen vuorovaikutuksen.

4) Avoin pilotti keväällä 2020

Helmikuussa 2020 alkaa avoin pilotti vertaistiedon ja vuorovaikutuksen jakamiseen digitaalisilla malleilla. Kokeilu tuottaa tietoa toimista malleista ja aiheistomuodoista, jotka ovat hyödynnettävissä tulevaisuudessa. Maataloustieteenpäivien posteriesityksessä demonstraatioesityksiä vuorovaikutteisen digitaalisen tiedon jakamisesta.

Avainsanat: digitaalisuus, vertaistiedon jakaminen, vuorovaikutteisuus, maatilayrittäjä 


\section{Johdanto}

Tässä hankkeessa selvitetään laadullisen tutkimuksen keinoin pilottikokeiluiden toimivuutta maatalousyrittäjien kouluttamisessa verkkovälitteisesti. Pilottikokeilut on suoritettu vuoden 2019 aikana Maatalousyrittäjien digitaaliset koulutusmateriaalit MataDigi -hankkeessa, joka on Manner-Suomen Maaseutuohjelma 2014 - 2020 ja Keski-Suomen ELY -keskuksen rahoittama tiedonvälityshanke. Tälle toiminnalle havaittiin käytännöstä lähtevä tarve mahdollistaa maatalousyrittäjien kouluttautuminen ja verkostoituminen myös etäyhteyksiä hyödyntämällä. Maatalousyrittäjien työ on kuormittavaa fyysisesti ja henkisesti (Perkiö-Mäkelä ym., 2016). Työn vaatiessa paljon läsnäoloa tilalla, ei irrottautuminen tilan ulkopuolella toteuttaviin koulutuksiin ole aina mahdollista. Maatalouden rakennekehitys on johtanut vähenevään maatalousyrittäjien määrään. Tästä syystä tilaa kehittävät yrittäjät eivät välttämättä löydä maantieteellisesti kovin läheltä niitä vertaisyrittäjiä, joiden kanssa sparrata toisiaan. Molemmat nämä tekijät ovat johtaneet tarpeeseen lähteä kehittämään maatalousyrittäjille kohdennettuja verkkovälitteisiä koulutuksia, joissa vuorovaikutus on toimivaa.

Asiantuntijuuden kasvussa elinikäisen ja kaikkiallisen, ubiikin oppimisen mahdollisuudet kasvattavat merkitystään (Häkkinen et al. 2013). Oppimisen ei enää nähdä tapahtuvan vain virallisten organisaatioiden tarjoamissa puitteissa ja koulutuksissa, vaan sitä voi tapahtua kaikkialla, tavoitteellisesti tai spontaanisti. Cope ja Kalantzis (2010) kuvaavat ubiikin oppimisen virstanpylväiksi $\mathrm{mm}$. oppimisen institutionaalisten, aikaan ja paikkaan sitoutuneiden rajojen hämärtämisen, toimijuuden siirtymisen opettajalta oppijalle, oppijoiden erojen näkemisen mahdollisuuksina, eri medioiden monipuolisen hyödyntämisen, metakognitiivisten taitojen kehittämisen tietotulvan hallitsemiseksi, oman tiedon yhdistämisen jaettuun yhteiseen tietoon sekä yhteistoiminnallisen tiedon kulttuurin kehittymisen.

Vuorovaikutteisuuden, vertaistiedon jakamisen ja yhteisen ongelmanratkaisun kautta pyritään mahdollistamaan yhteisöllinen oppiminen. Yrittäjä osallistuu yhteisölliseen tiedonrakentamiseen aktiivisena toimijana, omista kokemuksistaan ja aikaisemmasta tiedostaan käsin. Keskusteleva ote ja jaettuun tietoon pohjautuva ongelmanratkaisu auttavat soveltamaan uutta tietoa käytännön tilanteisiin ja muodostamaan yhteistä käsitystä käsiteltävästä aiheesta (Lallimo ja Veermans 2005). On kuitenkin olennaista ymmärtää, että verkoston luominen ja siinä toimiminen ei automaattisesti tarkoita yhteisöllisyyden muodostumista. Haasteet toiminnassa liittyvät $\mathrm{mm}$. luottamukseen ja sen rakentumiseen. (Parviainen 2006.)

Ensimmäisen vaiheen pienryhmien pilotteihin valikoituivat testattaviksi teknologioiksi Zoom verkkokokous, Flipgrid -videochat sekä sähköinen muistilappujärjestelmä Padlet. Valintoja erilaisten teknologioiden kesken määritti niiden mobiilikäyttöliittymä, helpohko käyttöönotto ja käyttäjälle ilmaisuus. Verrattaessa Zoom -verkkokokousta Skypen mahdollisuuksiin, on huomioitu useiden asiantuntijaorganisaatioiden käyttävän Skype for Business -sovellusta, jossa on empiirisesti todettu olevan yhteensovittamishaasteita kuluttajien käytössä olevan Skypen kanssa. Myös näytön jakaminen Skypessa vaatii verkko -osallistujien keskinäistä hyväksyntää, Zoomissa vastaavaa vaatimusta ei ole. Zoomin on myös todettu välittävän videoyhteyksiä hyvin jopa matkapuhelimen verkkoyhteyksien kautta. Flipgrid -videochat mahdollistaa lyhyiden, maksimissaan 2 minuutin pituisten videoiden tekemisen ja niihin vastaamisen omalla videolla. Padlet-sähköinen muistilappuseinä on työkalu useiden henkilöiden ja toimijoiden yhteiseen työskentelyyn. Padletin etuina ovat helppo käytettävyys sekä mahdollisuus reagoida ja vastata muiden käyttäjien tekemiin muistilappuihin.

\section{Tutkimusmenetelmät ja -aineisto}

Tutkimusmenetelmänä on tapaustutkimus, joka on luonteeltaan kvalitatiivinen tutkimus. Tapaustutkimukselle on ominaista kuvata ilmiö ja mitä siitä voidaan oppia (Eriksson ja Kovalainen 2008). Tässä kuvattavat tutkittavat case-tapaukset muodostuvat MataDigi -hankkeen verkkovälitteisistä 
koulutuskokeiluista. Ensimmäisen pilottivaiheen kokeilut toteutettiin vuoden 2019 aikana. Kokeiluista koostettiin kokemuksiin perustuva dokumentaatio kolmesta eri näkökulmasta:

1) pilotteihin osallistuvat maatalousyrittäjät Keski-Suomen alueelta ( $\mathrm{n}=8$ hlö)

2) pilottien toteutuksiin osallistuneet asiantuntijat ( $\mathrm{n}=7 \mathrm{hlö)}$

3) pilotteja valmistelleet ja vetäneet MataDigi -hankkeen toteuttajat ( $\mathrm{n}=4 \mathrm{hlö)}$.

Kolmesta eri näkökulmasta tarkasteltaessa saadaan laaja näkemys pilottien toteutuksista ja niiden kehittämiskohteista. Pilottien suunnittelussa ja toteutuksessa tavoitteena oli lisätä vuorovaikutusta erityisesti yrittäjien kesken, mutta tukea myös samanlaista keskustelua kuin kontaktitapaamisissa on. Tällöin vuorovaikutusta tapahtuu paitsi asiantuntijan ja osallistujien välisessä suhteessa molempiin suuntiin, mutta myös osallistujien kesken kokemusten ja näkemystenvaihdon myötä.

Pilotteihin osallistui kaksi erilaista ryhmää maatalousyrittäjiä. Ryhmät muodostettiin erilaisiksi, jotta päästiin seuraamaan kokemuksia ja toteutusten eroja ryhmien välillä. Ryhmässä 1 yrittäjät olivat samalta paikkakunnalta kotoisin ja heillä oli aiempaa, yhteistä kokemusta pienryhmässä toimimisesta. Näillä yrittäjillä oli myös selkeä yhteinen tavoite, johon he hakivat lisää ulkopuolista asiantuntijuutta pilottiin osallistumalla.

Ryhmässä 2 yrittäjät olivat maidontuottajia eri puolilta Keski-Suomea ja olleet aiemmin mukana pienryhmissä, mutta eivät samassa. Ryhmän verkkotapaamisten aiheiksi valikoitui maidontuotantoon liittyviä ja kaikkia ryhmäläisiä kiinnostavia aiheita. Molemmat ryhmät aloittivat työskentelyn ideoimalla yhteisessä aloitustapaamisessa ja sen jälkeen verkkotyökalun (Flipgrid tai Padlet) kautta aiheita, joita toivoivat pilottijakson aikana kokeiltavan.

Piloteissa toteutettaviksi valikoituivat seuraavanlaiset verkkovälitteiset työskentelymuodot:

\section{Kyselytunti verkossa}

Kyselytuntia edeltävästi yrittäjillä oli mahdollisuus esittää toiveita käsiteltävistä asioista mm. kertomalla omalla tilalla olevasta tilanteessa Flipgrid-videon välityksellä. Asiantuntija valmistautui näiden perusteella tilaisuuteen alustusta ja keskustelua varten. Verkkotapaamisissa asiantuntijatieto ja vertaiskokemukset yhdistyivät kaikkien hyödyksi. Onnistumisen kannalta olennaisia tekijöitä olivat yhteinen kiinnostava ja ajankohtainen aihe, etäosallistumismahdollisuus, verkko- ja sovellustestausmahdollisuus ennen tilaisuutta, helppokäyttöinen mobiilisovellus sekä yrittäjien kehittymishalu.

\section{Kasvukauden seuranta}

Kasvukauden tilanteiden seuranta ja jakaminen lyhyillä vidoilla, keskittyen ajankohtaisiin haasteisiin. Vertaistieto ja -kokemus olivat tukena ongelmien ratkaisuissa ja toimenpiteiden valinnassa. Vertaiset pääsivät katsomaan videoita ja antamaan kommentteja ja vinkkejä omalla videollaan.

\section{Virtuaalinen ja vuorovaikutteinen tilavierailu}

Tilavierailu toteutettiin virtuaalisesti Zoomin välityksellä. Osallistujat pääsivät vierailemaan etänä livetilanteessa kiinnostavassa kohteessa. Haastattelijan lisäksi vierailun toteutuksessa olivat mukana eläinlääkäri ja vierailutilan emäntä. Toteutuksen tekniset järjestelyt mahdollistivat reaaliaikaisen keskinäisen vuorovaikutuksen omalla äänellä kaikkien osallistujien kesken. Kokeilua varten JAMK:n digikeskuksessa rakennettiin kuvausteline, joka mahdollisti kuvan lähettämisen älypuhelimen kautta sekä äänen siirtämisen langattomien mikrofonien ja siirrettävän kaiuttimen kautta. 


\section{Tuloksia piloteista}

Kokeiluista kerättiin palautetta pilotteihin osallistuneilta maatalousyrittäjiltä, kokeiluiden toteutuksiin osallistuneilta asiantuntijoilta ja toteutusten organisoijilta. Kokemuksia kerättiin palautteiden muodossa, seuraamalla osallistujien aktiivisuutta ja sitoutumista pilottien toteutuksiin sekä havainnoimalla toteutuksia.

\section{Maatalousyrittäjien kokemukset}

Kokeilujen tuloksena havaittiin mukana olevien yrittäjien kokemusten verkkovälitteisistä tiedonvälitysmenetelmistä olevan pääosin positiivisia. Yhteisöllisen oppimisen tukemisen kannalta vuorovaikutuksen mahdollistaminen on yksi olennaisista työkaluihin ja järjestelmiin liittyvistä tekijöistä (Vuopala 2013), mikä pilottiin valikoituneiden työkalujen osalta toteutuikin.

Tämä oli ihan loistava, ei töhriintynyt aikaa matkoihin. Ei muuta, kun istun tähän näin ja olen mukana. Kolme minuuttia ja olen takaisin töissä..”-kasvitilan isäntä-

"Älyttömän hyvä, kun on pienet lapset, ei olisi voinut lähteä ajamaan Jyväskylään. Teknisesti tosi yksinkertainen. Voi olla jopa helpompi kysellä täällä verkossa." -maitotilan emäntä-

Oikeestaan ainoa mahdollinen, live ei onnistuisi muiden töiden takia." -maitotilan nuori isäntä-

"Helppohan näitä videoita on tehdä, kun saa vaan sormet oikealle kohdalle puhelimen näytössä.."

Maatalousyrittäjien verkostoituminen ja keskinäinen vuorovaikutus on todettu tärkeäksi osaksi osallistumista pienryhmiin ja ammatillisille opintomatkoille. Kun kokemustenvaihto tapahtuu verkkovälitteisesti, on huomioitava vähäisempi vuorovaikutus yrittäjien kesken. Tämän myös osa pilottiryhmiin osallistuneista yrittäjistä koki puutteeksi verkkovälitteisissä koulutuksissa. Aiemmissa hankkeissa on todettu yrittäjien vertaistuki henkistä hyvinvointia tukevaksi asiaksi (Haapakoski \& Salminen, 2014).

"Yhteinen bussimatka jäi nyt pois. Se on iso hyvinvointitekijä tilavierailuissa."

Pilottiryhmien välillä havaittiin eritasoista sitoutumista sekä vuorovaikutuksen luontevuutta verkkotapaamisissa. Yhteisöllisessä oppimisessa ryhmään liittyvien tekijöiden on havaittu muodostavan suuren osan yhteisöllistä oppimista edistävistä tekijöistä (Vuopala 2013). Keskustelun vastavuoroisuus ja aktiivinen osallistuminen ovat tärkeitä edistäjiä yhdessä luottamuksellisen ilmapiirin ja osallistujien aiemman osaamisen kanssa.

Ennestään yhteistyötä tehnyt ryhmä 1 keskusteli verkkotapaamisissa sekä asiantuntijoiden että muiden yrittäjien kanssa luontevasti ja joustavasti. Heillä oli myös suurimmalta osin videokuva päällä tapaamisten ajan, mikä vaikuttaa läsnäolon kokemukseen verkkotapaamisissa. Ryhmän 1 yrittäjät olivat myös laajalla joukolla mukana tapaamisissa ja muussa työskentelyssä pilottijakson aikana ja heitä yhdisti yhteisen tavoitteen eteen työskentely. Verkko-opiskelun vertaisvuorovaikutusta tutkinut Kääntä (2016) toteaa, että yhteisen tiedon käsittelyssä yhteiseen tavoitteeseen liittyen kannustettavaa on persoonallisten kokemusten jakamisen lisäksi myös eriävien näkökulmien esilletuominen, mikä onkin tärkeää yritystoiminnan kehittämisen kannalta toimivimpien tapojen löytämiseksi.

Ryhmässä 2 vuorovaikutusta oli pidettävä enemmän yllä tapaamisten fasilitoijan sekä asiantuntijoiden osalta. Ryhmän 2 edustus tapaamisissa oli kaiken kaikkiaan vähäisempää, kuin ryhmässä 1. Yhtenä todennäköisenä vaikuttajana oli ryhmän vieraus toisilleen, mitä vähentämään on tarpeen jatkossa miettiä erilaisia ryhmäytymistä tukevia toimenpiteitä. Ryhmäytymisen haasteet ja yhteisen tavoitteen puute todettiin myös Vuopalan (2013) tutkimuksessa yhdeksi selkeistä yhteisöllistä oppimista vaikeuttavista tekijöistä. Ryhmäytymisen tukeminen on havaittu olennaiseksi osaksi verkkotyöskentelyn sujuvuuden 
varmistamista, missä yhteydessä on käytetty niin kontaktitapaamisia, kuin mobiilityökaluja kuten Flipgrid-sovellusta osallistujien esittäytymiseksi toisilleen (Miettinen 2015). Haasteet ryhmän sisäisessä luottamuksessa voivat vaikuttaa haitallisesti vuorovaikutuksen määrään (Vuopala 2013) ja esimerkiksi kysymyksen asetteluun. Kääntä (2016) kuvaa, että kysymyksen esittämisellä voidaan ilmentää erilaisia tavoitteita mm. oman ymmärryksen jäsentämiseksi, oman tietämyksen haastamiseksi tai osoittamaan huomiota vaativa sisältö. Erityisesti oman osaamisen ja tietämyksen "rajoituksia" saattaa olla vaikea ilmaista muille ilman riittävää luottamusta, mikä osaltaan heikentää oppimis- ja vuorovaikutustilanteesta saatavaa hyötyä.

Osansa haasteista toi mukanaan uusien työkalujen omaksuminen. Työkalujen käytön tukea tarjottiin niin aloitustapaamisissa kuin myöhemmin verkkovälitteisesti Zoom-järjestelmässä. Täysin uusien työkalujen käyttöönotto pelkän verkkotuen varassa on todettu haasteelliseksi (Miettinen 2015), minkä vuoksi tukea oli tarjolla aluksi myös reaalimaailmassa. Yrittäjien tietotekniset taidot vaihtelivat suuresti ja jatkossa onkin varmistuttava siitä, että riittävät valmiudet työkalujen käyttöön on saavutettu ennen verkkotyöskentelyn aloittamista.

\section{Asiantuntijoiden kokemukset}

Verkkovälitteinen kouluttaminen ja tiedonvälitys vaatii uudenlaista toimintatapaa ja -ajattelua myös asiantuntijalta tai kouluttajalta. Vuorovaikutus koulutukseen osallistuvien henkilöiden kesken sekä suhteessa kouluttajaan on rakennettava ilman fyysistä läsnäoloa samassa tilassa. Erilaiset sovellukset eivät välttämättä ole entuudestaan tuttuja asiantuntijoille, joille koulutustoiminta ei ole päätyö. Tällöin tulee huomioida myös asiantuntijan tai kouluttajan tarvitsema aika tutustua itse käytettävään teknologiaan ja sen mahdollisuuksiin sekä vaatimuksiin. Mikäli hän hallinnoi yksin tilaisuutta, on myös tarpeen saavuttaa valmiudet ohjata ja tukea osallistujia mahdollisissa ongelmatilanteissa. Pilotteihin osallistuneet asiantuntijat olivat kiinnostuneita kokeilemaan verkkovälitteisiä tapaamisia ja kokivat sekä kokousjärjestelmän että toteutusmuodon toimiviksi.

\section{"Videot erinomaisia! Saa hyvin kuvan millainen kasvusto on ja mikä tilanne sillä hetkellä." -peltoasiantuntija-}

“Harvinaisen hyvä, viidessä minuutissa porukka sisään, voi suositella muillekin.”-talousasiantuntija-

\section{Toteuttajien kokemukset}

Pilottien perusteella ryhmien jäsenten motivaatio ja kiinnostus käsiteltäviin aiheisiin olivat keskeisinä tekijöinä vaikuttamassa osallistujien aktiivisuuteen niin videovälitteisen vertaisoppimisen kuin asiantuntijapalvelun käytössä. Ryhmien työskentelyä ohjattiin taukoaikoina eri tavoin aktivoimalla ja ohjeistamalla työskentelyä, mitä Vuopalan (2013) tutkimuksessa on havainnoitu erilaisten skriptien (työskentelyn käsikirjoitusten) ja tehtävänantojen vaikutusten kautta. Kyseisessä tutkimuksessa todettiin näillä olevan osin vaikutusta työskentelyn aktivointiin ja laatuun, erityisesti tehtävänannon tyypillä. Video vuorovaikutuksen välineenä ammatillisessa yhteydessä on uusi ja vieras asia, jonka tuottamiseen on osin korkea kynnys, vaikka osallistujat tuntisivat toisensa ennestään. Asiantuntijapalvelun tuominen ryhmälle webinaarina kyselytunnin muodossa on toimiva, nykyaikainen ja joustava menetelmä, joka tuotti toivotun laatukokemuksen pilottiin osallistuneille.

Yhteenvetona kokemuksista koottiin Taulukko 1, jossa ovat esillä erilaiset piloteissa käytetyt applikaatiot sekä niistä saadut kokemukset. 
Taulukko 1. Kooste piloteissa käytettyjen teknologioiden eduista ja haasteista

\begin{tabular}{|c|c|c|}
\hline $\begin{array}{l}\text { Zoom- } \\
\text { verkkokokous }\end{array}$ & $\begin{array}{l}\text { + Helppokäyttöinen ohjelma } \\
+ \text { Soveltuu hyvin mobiililaitteille } \\
+ \text { Toimii 4G-mobiiliyhteyksillä }\end{array}$ & $\begin{array}{l}\text { *Eri laitteilla toimiminen ja } \\
\text { näyttöruutu hieman erilaiset } \\
\text { *Vaatii riittävän verkkoyhteyden }\end{array}$ \\
\hline & $\begin{array}{l}\text { + Osallistujien sijainti vapaa } \\
\text { + Matka-aika- ja kustannussäästö }\end{array}$ & $\begin{array}{l}\text { *Ennakkotestaus vähentää selvästi } \\
\text { ongelmia verkkovälitteisissä } \\
\text { livetapaamisissa. }\end{array}$ \\
\hline $\begin{array}{l}\text { Flipgrid- } \\
\text { videochat }\end{array}$ & $\begin{array}{l}+2 \text { min video sopivan tiivis } \\
+ \text { Videon ja äänen yhdistämisellä } \\
\text { saa jaettua paljon tietoa } \\
+ \text { Kiinnostava katsoa toisten } \\
\text { videoita } \\
+ \text { Voidaan rajata tietylle ryhmälle }\end{array}$ & $\begin{array}{l}\text { *Sovelluksen käyttö vaatii alussa } \\
\text { harjoittelua } \\
\text { *Julkinen video vaatii rohkeutta - } \\
\text { omasta tilasta kertominen } \\
\text { kasvoilla ja äänellä } \\
\text { *Toisten videoiden } \\
\text { kommentointia ei tapahtunut eli } \\
\text { vuorovaikutus jäi toteutumatta }\end{array}$ \\
\hline Virtuaalinen navettavierailu & $\begin{array}{l}\text { + tautiriski pienenee } \\
\text { + osallistumismahdollisuus } \\
\text { yrittäjille, jotka eivät muuten } \\
\text { pääsisi } \\
\text { + vuorovaikutus tilan ja } \\
\text { osallistujien kesken } \\
\text { + kaikki osallistujat kuulevat ja } \\
\text { näkevät (kuin pienessä } \\
\text { ryhmässä) } \\
\text { + matka-aika- ja kustannussäästö }\end{array}$ & $\begin{array}{l}\text { *opintomatkojen aikana yrittäjien } \\
\text { verkostoituminen tärkeä, } \\
\text { virtuaalimatkassa ei onnistu } \\
\text { *tekninen toteutus } \\
\text { navettaympäristössä ja } \\
\text { toimivuus live-tilanteessa } \\
\text { *nettiyhteyden toimivuus koko } \\
\text { ajan ehdoton } \\
\text { *ennakkovalmistelut hyvin: } \\
\text { käsikirjoitus + aikataulu, } \\
\text { tekniikan testaus ja } \\
\text { toteuttajaroolitus }\end{array}$ \\
\hline
\end{tabular}

Osallistujan motivaatio videoiden kautta käsiteltävään aiheeseen vaikutti olevan keskeisin tekijä sille, kuinka aktiivisesti he jakoivat omia videohavaintojaan ja kokemuksiaan vertaisryhmässä sekä kuinka aktiivisesti he osallistuivat asiantuntijan kyselytuntiin. Ryan ja Decin (2000) motivaatioteoriaa mukaillen motivaatiota lisäävät toiminnan tuottama lisäarvo tai vahva ulkoinen pakko. Pitkäkestoinen tavoite tai toimintaa seuraava ulkoinen palkkio. Nämä sisäiset ja ulkoiset motivaatiotekijät olivat tunnistettavissa aktiivisten osallistujien puheista. Aktiivisuuden taustalla vaikuttivat mm. selkeä, pitkäkestoinen tavoite karjatalouden uudistamiselle ja viljelyn satoisuuden parantamiselle. Yksittäisellä toimijalla on mahdollisuus tukea ryhmän toimintaa, olipa hän osallistuja tai ohjaaja. Ohjaajan kannalta oleellista on ohjata toimintaa tarvittaessa kohti tavoitetta ja tukea vuorovaikutusta sen haasteellisissa vaiheissa esimerkiksi kysymysten esittämisen kautta (Vuopala 2013).

\section{Yhteenveto}

Pilottien toteuttaminen koettiin mielekkääksi sekä tarkoituksenmukaiseksi. Uusien, digitaalisten välineiden ja verkkovälitteisyyttä hyödyntävien koulutus- ja tiedonvälitysmallien käyttöönotto vastaa yrittäjäkentän tarpeisiin. Tehokas ja onnistunut koulutus edellyttää suunnittelijalta perehtymistä vuorovaikutuksen mahdollistamiseen paitsi osallistamisen, myös teknisten toteutusratkaisuiden kautta. Nämä molemmat vaativat huolellista valmistautumista ja kohderyhmän lähtötason tuntemista.

Ensimmäisen vaiheen pilottien aikana tunnistettiin kaksi erityistä haastetta, yrittäjien keskinäinen kommunikaatio sekä teknologian omaksuminen. Luottamuksen ja luontevan vuorovaikutuksen rakentaminen osallistujien välille on tärkeää koulutuskokonaisuuden onnistumiselle tavoitellulla tavalla. Teknologian omaksumisen haasteita voidaan ratkaista ennakkoon testaamalla ja tarjoamalla osallistujille ohjausta työkalujen käyttöön.

Osallistujien näkökulmasta uuden tiedon hankkiminen kotoa käsin on kustannustehokasta. Syvällisen oppimisen tukemisessa muiden henkilöiden kanssa vuorovaikutuksessa oleminen on merkityksellistä. Koska verkkovälitteisestä toteutuksesta puuttuu fyysisen läsnäolon tuottama erilaisten persoonien vaatima tila, voi arempienkin henkilöiden olla helpompaa osallistua keskusteluun omasta tutusta ympäristöstä käsin. 
Pilottien avulla todettiin digitalisaation mahdollisuuksien jalkauttamisen olevan kannattavaa ja kaikkia osapuolia auttavaa toimintaa. Hankkeen tapahtumissa erilaisten uusien teknologioiden käyttöönotto on turvallista ja ohjattua, jolloin madalletaan kynnystä tarttua etäkoulutusten mahdollisuuksiin. Vuorovaikutteisuuden testaaminen ohjatusti eri tavoin lisää asiantuntijoiden osaamista huomioida verkkovälitteisten osallistujien panos tapahtuman sisältöön. Verkkovälitteisten tapaamisten mahdollistamat aika- ja kustannussäästöt ovat merkittävä etu maatalousyrittäjille.

Verkkovälitteisyys ei kuitenkaan palvele kaikissa tilanteissa ja maatalousyrittäjien tapaamisilla kasvokkain on erittäin suuri merkitys luottamuksen ja keskusteluyhteyden rakentumisessa. Sillä on myös vaikutusta yrittäjien hyvinvointiin sosiaalisen kanssakäymisen myötä. Yhdistämällä molempia tapoja, on mahdollisuus rakentaa tulevista yrittäjille suunnatuista koulutuksista digitalisaatiota hyödyntävää ja yrittäjien osaamista sekä hyvinvointia tukevaa koulutustoimintaa.

\section{Lähteet}

Cope, W. \& Kalantzis, M. 2010. Ubiquitous learning: An agenda for educational transformation. Proceedings of the 6th International Conference on Networked Learning.

https://www.researchgate.net/publication/228347819_Ubiquitous_learning_An_agenda_for_education al_transformation

Eriksson, P. \& Kovalainen, A. 2008. Qualitative methods in business research. Sage publications. https://doi.org/10.4135/9780857028044

Haapakoski, M. \& Salminen, S. 2014. Pohdinta tuloksiin liittyen. Teoksessa: Haapakoski, M. (toim.). Happy Farmer. Eväitä maatilayrittäjien jaksamiseen. Jyväskylän ammattikorkeakoulun julkaisuja 184.

Häkkinen, P., Juntunen, M. \& Laakkonen, I. 2013. Verkko-oppiminen murroksessa - oppijalähtöiset ja yhteisölliset oppimisympäristöt oppimiskäsityksen haastajina. Teoksessa Vuorovaikutuksen jänniteitä ja oppimisen säröjä. Aikuispedagogiikan haasteiden äärellä. Toim. Hakala, J.T. \& Kiviniemi, K. Luokanopettajien aikuiskoulutuksen 25-vuotisjuhlajulkaisu. Kokkolan yliopistokeskus Chydenius. https://jyx.jyu.fi/bitstream/handle/123456789/48383/978-951-39-5376-8.pdf

Kääntä, L. 2016. Hyviä pointteja - Vuorovaikutus vertaisten kesken institutionaalisessa verkkokeskustelussa. Acta Wasaensia 359. Kielitiede 50. https://www.univaasa.fi/materiaali/pdf/isbn_978-952-476-701-9.pdf

Lallimo, J. \& Veermans, M. 2005. Yhteisöllisen verkko-oppimisen rakenteita. Helsingin yliopiston Avoimen yliopiston julkaisusarja 1. https://www.avoin.helsinki.fi/esittely/yhteisollisenverkkooppimisen.pdf

Miettinen, M. 2015. Opettajankoulutusta verkossa? Verkkopilotti opettajankouluttajien ja opiskelijoiden näkökulmasta. Jyväskylän ammattikorkeakoulun julkaisuja 197.

https://www.theseus.fi/bitstream/handle/10024/86886/JAMKJULKAISUJA1972015_web.pdf?sequen $\mathrm{ce}=1 \&$ is Allowed $=\mathrm{y}$

Parviainen, J. 2006. Kollektiivinen tiedonrakentaminen asiantuntijatyössä. Teoksessa: Parviainen, J. (toim.). Kollektiivinen asiantuntijuus. Tampereen yliopistopaino.

https://trepo.tuni.fi/bitstream/handle/10024/65372/kollektiivinen_asiantuntijuus_2006.pdf

Perkiö-Mäkelä, M., Hirvonen, M., Kinnunen, B., Koponen, M., Louhelainen, K., Mäittälä, J., Sipponen, J. \& Torpström, A. 2016. Työterveys ja maatalous Suomessa 2014. Työterveyslaitos.

http://www.julkari.fi/handle/10024/130362

Ryan, R.M. \& Deci, E.L. 2000. Self-Determination Theory and the Facilitation of Intrinsic Motivation, Social Development, and Well-Being. https://selfdeterminationtheory.org/SDT/documents/2000_RyanDeci_SDT.pdf

Vuopala, E. 2013. Onnistuneen yhteisöllisen verkko-oppimisen edellytykset - Näkökulmina yliopistoopiskelijoiden kokemukset ja verkkovuorovaikutus. ACTA UNIVERSITATIS OULUENSIS E Scientiae Rerum Socialium 133. http://jultika.oulu.fi/files/isbn9789526202259.pdf 